\title{
PENGARUH KONSELING GIZI PADA ASUPAN MAKAN REMAJA OBESITAS DI SMP KRISTEN WOLOAN KOTA TOMOHON
}

\author{
Henry S. Imbar ${ }^{1, a}$. Jufri Sineke,2,a Chandra Rugian $^{3}$ \\ 1,2,3, Jursan Gizi Poltekkes Kemenkes Manado Idonesia

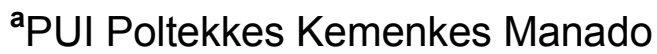 \\ hnrmbr@gmail.com
}

\begin{abstract}
Feeding intake is all types of food and beverages consumed by the human body food is also one of the very basic human needs because it affects the existence and survival of human today. This study aims to determine the effect of nutritional counseling on the intake of eating obese adolescents and to know the intake of food before and after counseling in SMP Kristen Woloan Tomohon.This type of research is a type of preexperimental study with a pre-test design of one gramoup design. The number of samples used in this study were 20 respondents. Feed intake data was taken by first measuring the treatment in the study gramoup (pre-test) with a 24-hour recall method carried out 3 days, and providing nutritional counseling, and measured again after being given nutritional counseling treatment (post test) with a 3-day recall method . Data analysis using wilcoxon analysis from the results showed that energy intake, protein intake, fat intake, and carbohydrate intake experienced penuruna after being given counseling. Based on the results of statistical analysis using wilcoxon test $\rho$ $=0.000 \quad(<0.05)$ which means there is influence counseling on feeding intake of adolescent obesity. Conclusion There is the influence of nutritional counseling on the intake of eating obese adolescents
\end{abstract}

\section{Keywords: Nutrition Counseling, Feeding Feed, Obesity}

Asupan makan adalah semua jenis makanan dan minuman yang di konsumsi oleh tubuh manusia makanan juga merupakan salah satu kebutuhan manusia yangsangat mendasar karena berpengaruh pada eksistensi dan ketahanan hidup manusia saat ini (Yusnita dan, Ismawati, 2014).

Indonesia menurut data Riskesdas menunjukan bahwa prevalensi gizi lebih pada usia 13-15 Tahun secara nasional sebesar 10,8\%, yang terdiri dari gemuk 8,3 $\%$ dan 2,5\% sangatgemuk (obesitas) untuk 16-18 tahun untuk berat badan lebih $13,5 \%$ dan obesitas 15,4\% Prevalensi kegemukan pada anak 13-15 Tahun di Sulawesi utara $2,7 \%$. Sebanyak 7 kabupaten/kota dengan prevalensi gemuk diatas prevalensi Provinsi Sulawesi Utara, yaitu Minahasa, Kepulauan Sangihe, Bolaang Mongondow Timur, Kota Manado, Kota Bitung, Kota Tomohon, Kota Kotamobagu, sementara itu Prevalensi gemuk pada remaja umur 16-18 Tahun sebanyak 2,6\% enam kabupaten/kota dengan Prevalensi gemuk diatas Prevalensi Provinsi Sulawesi Utara, yaitu Kota Tomohon, Bolaang Mongondow Timur, Kota Manado, Minahasa Utara, Kota Kotamobagu, dan terakhir yaitu Kepulauan Talaud (Balitbangkes, 2013).

Berdasarkan latar belakang menunjukkan bahwa masalah obesitas sering terjadi di daerah perkotaan seperti contohnya ada tiga daerah perkotaan yang memiliki Prevalensi obesitas yang menempati peringkat 5 besar yaitu Kota Tomohon, Kota Manado dan Kotamobagu. Berdasarkan hal itu maka obesitas perlu juga mendapat perhatian dari petugas kesehatan terutama petugas gizi karena masalah gizi menjadi salah satu masalah kesehatan di negara berkembang seperti indonesia. Indonesia saat ini juga diperhadapkan dengan masalah obesitas yang terus meningkat dengan pesat terutama di daerah perkotaan.

Berdasarkan masalah diatas, maka peneliti tertarik untuk meneliti tentang 
pengaruh konseling gizi pada asupan makan remaja obesitas di SMP Kristen Woloan Kota Tomohon.

\section{METODE}

- Jenis penelitian ini adalah jenis penelitian pre eksprimental dengan rancangan pre-test one gramoup design. Sampel dalam penelitian ini adalah 20 orang responden, peneliti melakukan pengukuran awal untukmengukur asupan makanan sebelum memberikan perlakuan pada kelompok studi (pre-test) dengan metode recall 24 jam yang dilaksanakan 3 hari, dan memberikan konseling gizi, dan di ukur kembali sesudah diberikan perlakuan konseling gizi (post test) dengan metode recall 3 hari. Penelitian dilaksanakan pada bulan Juni dan Juli tahun 2019. Analisis data diawali analisis univariat kemudian uji normalitas kemudian dilanjutkan dengan analisis bivariat yaitu uji wilcoxon.

HASIL

Karakteristik Sampel

Adapun hasil yang diperoleh dari penelitian ini adalah sebagai berikut :

Tabel 1. Distribusi Responden

\begin{tabular}{lcc}
\hline Jenis Kelamin & $\mathbf{n}$ & $\mathbf{\%}$ \\
\hline Laki-laki & 12 & 60 \\
Perempuan & 8 & 40 \\
Total & $\mathbf{2 0}$ & $\mathbf{1 0 0}$ \\
\hline Umur (Thn) & $\mathbf{n}$ & $\%$ \\
\hline 12 & & \\
13 & 6 & 30 \\
14 & 9 & 20 \\
15 & 4 & 5 \\
\hline Total & 1 & $\mathbf{1 0 0}$ \\
\hline
\end{tabular}

Pada penelitian ini sampel laki-laki berjumlah 12 orang $(60 \%)$ dan perempuan berjumlah 8 orang (40\%) dan kategori umur 13 tahun paling banyak yang berstatus gizi obesitas yaitu 9 orang responden dengan presentase $45 \%$ dan terendah umur 15 tahun 1 orang responden dengan presentase $5 \%$.

Tabel 2. Asupan Energi Sebelum dan Sesudah Konseling

\begin{tabular}{llllllc}
\hline Kategori & Mean & Median & SD & Min & Max & $\boldsymbol{P}$ \\
\hline Sebelum & 2445 & 2551 & 1,8 & 2135 & 2631 & 0,000 \\
Sesudah & 2342 & 2441 & 1,9 & 2060 & 2635 & \\
\hline Kategori & Mean & Median & SD & Min & Max & $\boldsymbol{P}$ \\
Sebelum & 69,3 & 70,5 & 6,9 & 56 & 80 & 0,00 \\
Sesudah & 62,5 & 64 & 7,9 & 51 & 78 & \\
\hline
\end{tabular}

Berdasrkan Tabel 2 menunjukkan bahwa asupan energi sebelum diberikan konseling nilai rata-rata adalah 2445 kkal dengan standar deviasi 1,8 sesudah 
diberikan konseling nilai rata-rata asupan energi yaitu 2342 kkal dengan standar deviasi 1,9. Dari hasil diatas nilai rata-rata asupan energi mengalami penurunan setelah diberikan konseling sebesar $103 \mathrm{kkal}$.

Salah satu faktor yang dapat mempengarugi terjadinya obesitas pada remaja yaitu tingkat pengetahuan gizi remaja. Dengan adanya pengetahuan gizi yang kurang pada sebagian besar remaja kelompok obesitas sehingga memungkinkan mereka kurang baik dalam memilih menu makanan yang bergizi.

Berdasarkan hasil analisis statistik dengan menggunakan uji wilcoxon $=0,000$ $<0,05$ maka Ho ditolak, berarti terdapat pengaruh asupan lemak sebelum konseling dan sesudah konseling di SMP Kristen Woloan Kota Tomohon. Dan terdapat 18 remaja obesitas yang mengalami penuruan asupan lemak setelah diberikan konseling menurut hasil dari negative ranks atau selisih (negatif) antara asupan lemak sebelum dan sesudah diberikan konseling.

Tabel 2 pun menunjukkan bahwa asupan protein sebelum diberikan konseling nilai rata-rata adalah 69,3 gram dengan standar deviasi 6,9 kemudian sesudah diberikan konseling nilai rata-rata asupan protein adalah 62,5 gram dan standar deviasi 7,9. Dari hasil rata-rata asupan protein mengalami penurunan setelah diberikan konseling sebesar 6,8 gram.

Berdasarkan hasil analisis statistik dengan menggunakan uji wilcoxon $=0,000$ $<0,05$ maka Ho ditolak, berarti terdapat pengaruh asupan protein sebelum konseling dan sesudah konseling di SMP Kristen Woloan Kota Tomohon. Kemudian dari hasil negative ranks atau selisih (negatif) terdapat 19 remaja obesitas yang mengalami penurunan asupan protein setelah diberikan konseling

Tabel 3. Asupan Lemak Sebelum Sesudah

\begin{tabular}{llllrlc}
\hline Kategori & Mean & Median & SD & Min & Max & $\boldsymbol{P}$ \\
\hline Sebelum & 87,7 & 89,5 & 4,8 & 81 & 93 & 0,00 \\
Sesudah & 78,8 & 79,5 & 8,2 & 64 & 94 & \\
\hline
\end{tabular}

Berdasarkan Tabel 3 menunjukkan bahwa asupan lemak sebelum diberikan konseling nilai rata-rata adalah 87,7gram dengan standar deviasi 4,8 dan sesudah diberikan konseling nilai rata-rata asupan lemak adalah 78,8 dan standar deviasi 8,2 . Dari hasil penelitian nilai rata-rata asupan lemak mengalami penurunan setelah diberikan konseling sebesar 8,9 gram.

Berdasarkan hasil analisis statistik dengan menggunakan uji wilcoxon $=0,000$ $<0,05$ maka Ho ditolak, berarti terdapat pengaruh asupan lemak sebelum konseling dan sesudah konseling di SMP Kristen Woloan Kota Tomohon. Dan terdapat 18 remaja obesitas yang mengalami penuruan asupan lemak setelah diberikan konseling menurut hasil dari negative ranks atau selisih (negatif) antara asupan lemak sebelum dan sesudah diberikan konseling.

Tabel 4. Asupan Karbohidrat Sebelum Sesudah

\begin{tabular}{|c|c|c|c|c|c|c|c|}
\hline Kategori & & Mean & Median & SD & Min & Max & $\bar{P}$ \\
\hline Sebelum & 381 & 405 & 4,6 & 310 & 441 & 0,00 & \\
\hline Sesudah & 331 & 345 & 5,2 & 240 & 451 & & \\
\hline
\end{tabular}


Berdasarkan tabel 4 menunjukkan bahwa asupan karbohidrat sebelum diberikan konseling nilai rata-rata asupan karbohidrat adalah 381gram dengan standar deviasi 4,6 kemudian sesudah diberikan konseling nilai rata-rata adalah 331gram dan standar deviasi 5,2. Dari hasil penelitian nilai rata-rata asupan karbohidrat mengalami penuruan setelah diberikan konseling sebesar 50gram.

Akibat kurangnya pengetahuan banyak remaja saat ini pada saat berada di lingkungan sekolah gemar mengkonsumsi makanan seperti nasi goreng, cilok, batagor, mie ayam, bakso, dan siomay yang mengandung karbohidrat (Kurdanti, dkk, 2015). Berdasarkan hasil analisis statistik dengan menggunakan uji wilcoxon $p=$ $0,000(<0,05)$ maka Ho ditolak, berarti terdapat pengaruh asupan karbohidrat sebelum konseling dan sesudah konseling d SMP Kristen Woloan Kota Tomohon.

Kemudian dari hasil negative ranks atau selisih (negatif) terdapat 18 remaja obesitas yang mengalami penuruan asupan karbohidrat setelah diberikan konseling.

\section{PEMBAHASAN}

Remaja perempuan relatif memiliki tingkat prevalensi lebih tinggi kegemukannya dibandingkan dengan remaja laki-laki, dengan prevalensinya remaja perempuan sejumlah (1,5\%) sedangkan remaja laki-laki 1,3\% (Kurdanti, dkk, 2015).

Obesitas yang terjadi pada anak merupakan salah satu faktor penentu yang sangat penting pada kejadian obesitas di usia dewasa dan salah satu kelompok umur yang paling berisiko terjadinya obesitas yakni anak usia sekolahlah yang paling berisiko terjadi obesitas (Tuerah, dkk, 2015).

Sebagian besar kejadian masalah gizi lebih atau kurang dapat dihindari apabila remaja mempunyai pengetahuan yang cukup tentang memelihara status gizi dan mengatur makan (Suryaputra dan Nadhiroh, 2012).

Saat ini pemilihan makan tidak lagi didasari pada kandungan zat gizi yang ada akan tetapi hanya sekedar untuk bersosialisasi dan kesenangan seperti banyak nya siswa/siswi yang sering mengkonsumsi makanan tinggi lemak di sekolah mereka seperti gorengan dan jajanan instan cepat saji yang semua itu mengandung lemak tinggi (Restuastuti, dkk, 2016).

Walaupun kebutuhan energi dan zat-zat gizi lebih besar pada remaja daripada dewasa, tetapi ada sebagian remaja yang makannya terlalu banyak melebihi kebutuhannya sehingga menjadi gemuk aktiv berolahraga dan melakukan pengaturan makan adalah cara untuk menurunkan berat badan pada umumnya makanan yang serat tinggi mengandung sedikit energi dengan demikian dapat membantu menurunkan berat badan, di samping itu serat dapat menimbulkan rasa kenyang sehingga dapat menghindari ngemil makanan/kue. (Hasdianah, dkk, 2014).

Ada beberapa faktor yang berpengaruh pada kejadian obesitas remaja seperti faktor genetik, adanaya pola makan berlebih, kurang gerak atau olahraga, adanya pengaruh emosional dan adanya pengaruh faktor lingkungan (Salam, 2010).

Remaja rentan akan resiko obesitas sebaiknya diberi edukasi dengan media yaitu untuk memperbaiki asupan makan khususnya asupan energi dengan tetap memperhatikan keseimbangan asupan zat gizi protein dan karbohidrat (Kurdanti, dkk, 2015).

Berdasarkan hasil analisis statistik dengan menggunakan uji Wilcoxon $=0,000$ $<0,05$ maka $\mathrm{HO}$ ditolak, itu berarti terdapat pengaruh konseling pada asupan makan remaja obesitas di SMP Kristen Woloan Kota Tomohon. sehingga disimpulkan bahwa terdapat pengaruh atau perubahan signifikan terhadap remaja obesitas sebelum dilakukan konseling dan sesudah dilakukan konseling. Konseling gizi diperlukan untuk meningkatkan pemahaman klien serta mendorong klien agar supaya bisa membuat penyelesaian terhadap apa yang menjadi masalahnya. Selain itu menurut Paruntu (2014), konseling gizi diperlukan juga agar terjadi perubahan menjadi gaya hidup sehat dan untuk melakukan perubahan gaya hidup sehat tersebut dibutuhkan motivasi yang besar dan lingkungan yang mendukung. 


\section{KESIMPULAN}

Nilai rata-rata asupan energi sebelum diberikan konseling nilai rata-rata adalah 2445 kkal dengan standar deviasi 1,8 sesudah diberikan konseling nilai rata- rata asupan energi yaitu 2342 kkal dengan standar deviasi 1,9. Nilai rata-rata asupan protein adalah 69,3 gram dengan standar deviasi 6,9 kemudian sesudah diberikan konseling nilai rata-rata asupan protein adalah 62,5 gram dan standar deviasi 7,9 . Nilai ratarata adalah asupan lemak adalah 87,7gram dengan standar deviasi 4,8 dan sesudah diberikan konseling nilai rata-rata asupan lemak adalah 78,8 dan standar deviasi 8,2. Nilai rata-rata asupan karbohidrat adalah 381gram dengan standar deviasi 4,6 kemudian sesudah diberikan konseling nilai rata-rata adalah 331 gram dan standar deviasi 5,2. Terdapat pengaruh konseling gizi terhadap asupan makan pada remaja obesitas di SMP Kristen Woloan Kota Tomohon dengan uji statistik uji wilcoxon = $0,000<0,05$.

\section{DAFTAR PUSTAKA}

Balitbang Kemenkes RI, 2013. Riset Kesehatan Dasar; RISKESDAS

iptaningtyas, (2013). Teori Dan Panduan Konseling Gizi. Penerbit Gramaha Ilmu Yogyakarta 2013.

Cornelia, Sumedi, Anwar, Ramayulis, Iwaningsih, Kresnawan, Nurlita, (2016). Konseling Gizi, Proses Komunikasi, Tata Laksana, Serta Aplikasi Konseling Gizi Pada Berbagai Diet. Penerbit Penebar Plus, Jakarta 2016.

Hasdianah, Siyoto, Peristyowati, (2014). Gizi, Pemanfaatan Gizi, Diet, Dan Obesitas. Penerbit Medical Book, Yogyakarta, Februari 2014.

Kurdanti, Suryani, Syamsiatun, Siwi, Ardianty, Multikaningsih, Sholihah, (2015). Faktor-faktor Yang Mempengaruhi Kejadian Obesitas Pada Remaja. Jurnal Gizi Klinik Indonesia Volume 11 April 2015, Hal 181-190.

Restuastuti, Jihadi, Ernalisa, (2016). Hubungan Pola Makan Dan Aktivitas Fisik Terhadap Obesitas Pada Remaja di SMA Negeri 5 Pekanbaru Jurnal Jom FK Volume 3 Nomor 1 Februari 2016.

Salam. A. (2010). Faktor Risiko Kejadian Obesitas Pada Remaja. Jurnal MKMI Volume 6 Nomor 3 Juli 2010, Hal 185-190.

Suryaputra, Nadhiroh, (2012). Perbedaan Pola Makan dan Aktivitas Fisik Antara Remaja Obesitas Dengan Non Obesitas. Makara, Kesehatan, volume. 16, Nomor. 1, juni 2012.

Tuerah, Manampiring, Fatimawali, (2014). Prevalensi Obesitas Pada Remaja Di SMA Kristen Tumou Tou Kota Bitung. Junal E-BIOMEDIK Volume 2 Nomor 2 Juli 2014.

Yusnita, Ismawati, (2014). Hubungan Asupan Makanan Dengan Status Gizi Dan Perilaku Adaptif Anak Autis Di Paud Abk Mutiara Kasih Trenggalek. E-Jurnal Boga volume 3 Nomor 1 Februari 2014. 